\title{
Replicating satellite RNA induces sequence-specific DNA methylation and truncated transcripts in plants
}

\author{
MING-BO WANG, S. VARSHA WESLEY, E. JEAN FINNEGAN, NEIL A. SMITH, \\ and PETER M. WATERHOUSE \\ CSIRO Plant Industry, Canberra, ACT 2601, Australia
}

\begin{abstract}
Tobacco plants were transformed with a chimeric transgene comprising sequences encoding $\beta$-glucuronidase (GUS) and the satellite RNA (satRNA) of cereal yellow dwarf luteovirus. When transgenic plants were infected with potato leafroll luteovirus (PLRV), which replicated the transgene-derived satRNA to a high level, the satellite sequence of the GUS:Sat transgene became densely methylated. Within the satellite region, all 86 cytosines in the upper strand and $\mathbf{7 3}$ of the $\mathbf{7 5}$ cytosines in the lower strand were either partially or fully methylated. In contrast, very low levels of DNA methylation were detected in the satellite sequence of the transgene in uninfected plants and in the flanking nonsatellite sequences in both infected and uninfected plants. Substantial amounts of truncated GUS:Sat RNA accumulated in the satRNA-replicating plants, and most of the molecules terminated at nucleotides within the first $60 \mathrm{bp}$ of the satellite sequence. Whereas this RNA truncation was associated with high levels of satRNA replication, it appeared to be independent of the levels of DNA methylation in the satellite sequence, suggesting that it is not caused by methylation. All the sequenced GUS:Sat DNA molecules were hypermethylated in plants with replicating satRNA despite the phloem restriction of the helper PLRV. Also, small, sense and antisense $\sim 22 \mathrm{nt} \mathrm{RNAs,} \mathrm{derived} \mathrm{from} \mathrm{the}$ satRNA, were associated with the replicating satellite. These results suggest that the sequence-specific DNA methylation spread into cells in which no satRNA replication occurred and that this was mediated by the spread of unamplified satRNA and/or its associated 22 nt RNA molecules.
\end{abstract}

Keywords: double-stranded RNA; gene silencing; RNA-directed DNA methylation; luteovirus; RNA interference; transcription elongation

\section{INTRODUCTION}

RNA-directed DNA methylation (RdDM) was first demonstrated by Wassenegger et al. (1994), who showed that nuclear replication of potato spindle tuber viroid (PSTVd) induced heavy de novo methylation of a PSTVd sequence integrated into the tobacco genome. More recently, Jones et al. $(1998,1999)$ showed that cytoplasmically replicating RNA of plant poty- and potexviruses can also induce methylation of homologous nuclear viral transgene sequences. An important characteristic of RdDM is its sequence specificity: only the DNA sequences that are homologous to the replicating RNAs become hypermethylated (Jones et al., 1999; Pélissier et al., 1999). This suggests an involvement of

Reprint requests to: Ming-Bo Wang or Peter Waterhouse, CSIRO Plant Industry, Clunies Ross Street, GPO Box 1600, Canberra, ACT 2601, Australia; e-mail: m.wang@pi.csiro.au or p.waterhouse@ pi.csiro.au. direct RNA/DNA interaction, possibly RNA/DNA pairing, in the process of RdDM (Jones et al., 1999; Pélissier et al., 1999).

The biological role of RdDM remains unclear. Based on their finding that DNA sequences as short as $30 \mathrm{bp}$ could be targeted for methylation by PSTVd, Pélissier and Wassenegger (2000) proposed that RdDM induced by plant viroids may account for their pathogenicity: replicating viroid RNA may cause methylation of homologous sequences and consequently downregulation of certain endogenous genes, leading to disease symptoms. It was also proposed that the de novo DNA methylation induced by replicating viral RNA is responsible for the maintenance of virus-induced nuclear gene silencing (Jones et al., 1999). In this case, DNA methylation is thought to be required for the production of silence-inducing aberrant transgene RNA after the virus is removed from the plant cells (Jones et al., 1999). De novo DNA methylation of coding se- 
quences is frequently found to be associated with posttranscriptional gene silencing (PTGS) in plants (Stam et al., 1997). Although DNA/DNA interactions may account for some cases of this de novo methylation (Luff et al., 1999), the coding sequence-specific nature of the methylation suggests that, in many cases of PTGS, the methylation is also RNA directed.

Although the methylation of the promoter region of a gene can lead to transcriptional inactivation (Stam et al., 1997), the effect on gene expression of methylation in the coding region remains unclear. DNA methylation can inhibit elongation of transcription in Neurospora crassa (Rountree \& Selker, 1997) and in another fungus, Ascobolus immersus, methylation of the coding region has been associated with the production of truncated RNAs (Barry et al., 1993). The sizes of these transcripts indicated that the truncations had occurred in the region of methylated DNA, also suggesting that methylation can block transcript elongation. However, there is no clear evidence that DNA methylation leads to premature termination of transcription in plants, and the role of DNA methylation in PTGS remains elusive. Furthermore, whereas RdDM is associated with some cases of virus-induced gene silencing (Jones et al., 1999), it has yet to be demonstrated that viroid-induced methylation can cause gene silencing.

In this study, we examined whether replication of the viroid-like satellite RNA (satRNA) of cereal yellow dwarf luteovirus (CYDV) could affect the epigenetic status of nuclear genes so as to induce PTGS in plants. PTGS can be systemically transmissible in plants, possibly involving mobile signal RNA molecules (Jorgensen et al., 1998; Wassenegger \& Pélissier, 1999) and such RNAs may resemble viroids (Voinnet et al., 1998). The CYDV satRNA (Miller et al., 1991) is viroid-like, as it is small (322 nt), circular, has extensive self-complementarity, and uses the rolling-circle replication strategy (reviewed in Symons, 1997). In this replication, the plus strand RNA is copied to produce minus strand RNA and vice versa; both strands undergo self-cleavage to produce unit-length RNAs (and multimers by inefficient cleavage), and the unit-length RNAs are circularized. However, unlike viroid RNA, which replicates autonomously using host-encoded RNA polymerase and is nonencapsidated, the satRNA replication depends entirely on the presence of a helper virus, which provides the RNAdependent RNA polymerase required for replication and coat protein for encapsidation. Because the helper virus only replicates in the cytoplasm of phloem and phloem-associated cells, the replication of the satellite RNA presumably also has these restrictions. This is in contrast to the nuclear-localized replication of many viroids, including PSTVd, in a wide range of cells.

We found that the satRNA of CYDV, when replicating in the presence of a helper virus, efficiently induced dense de novo methylation of its nuclear transgene sequence. Bisulphite-assisted genomic sequencing
(Clark et al., 1994) revealed that the satRNA-induced methylation was mostly confined to the satellite region of the GUS-satellite fusion transgene, resembling the RdDM induced by PSTVd and by poty-/potexviruses. We also detected a substantial amount of truncated transgene RNAs in the satRNA-replicating plant, and the sites of RNA truncation coincided with the $5^{\prime}$ region of the satellite sequence of the chimeric transgene. Our results support the notion that double-stranded RNA is an effective trigger of both RdDM and PTGS in plants.

\section{RESULTS}

\section{Transgene-derived CYDV satRNA could be replicated by PLRV}

Two constructs (Fig. 1A) were introduced into tobacco through Agrobacterium-mediated transformation. One

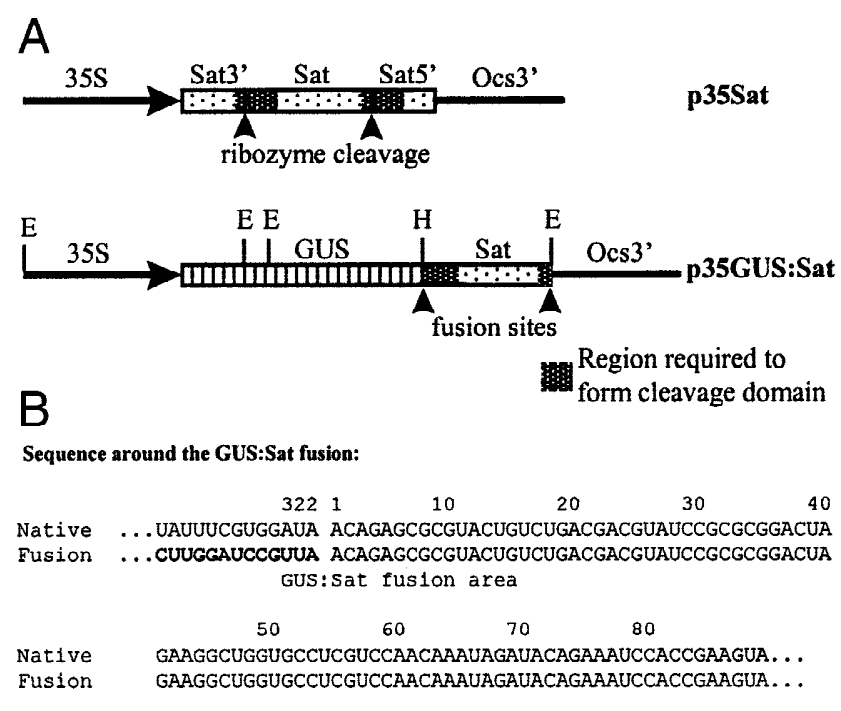

Sequence around the Sat:Ocs fusion:

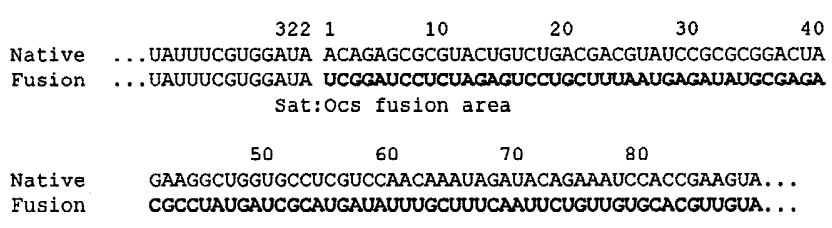

FIGURE 1. A: Schematic diagrams of constructs used in tobacco transformation. 35S: cauliflower mosaic virus 35S promoter. Ocs3': $3^{\prime}$ region of Agrobacterium octopine synthase gene. Sat: the fulllength sequence of monomeric form of the CYDV satRNA. Sat3': the $3^{\prime}$ half of the satellite sequence from nt 148 to the $3^{\prime}$ end. Sat5': the $5^{\prime}$ half of the satellite sequence from the $5^{\prime}$ end to nt 147 . GUS: $\beta$-glucuronidase gene sequence. E and $\mathrm{H}$ : EcoRV and Hindlll restriction sites used in Southern blot hybridization. B: The sequences around the GUS:Sat and the Sat:Ocs3' fusion sites in the p35GUS:Sat transgene. The bold letters indicate sequences from the polyliner and Ocs $3^{\prime}$ in the fusion transgene that correspond to the regions required for formation of the ribozyme cleavage domain of the plusstrand CYDV satRNA. The numbers above the sequences correspond to the nucleotides of the monomeric form of CYDV satellite RNA. 
(p35Sat) contains the full-length sequence of the monomeric form of CYDV satRNA, fused at the $5^{\prime}$ end with the $3^{\prime}$ half of the satellite sequence and at the $3^{\prime}$ end with the $5^{\prime}$ half of the satellite sequence. Following transcription, this construct should generate two native self-cleaving ribozyme domains of the plus-strand CYDV satRNA (Miller et al., 1991), allowing the production of functional monomeric satRNA. The second construct (p35GUS:Sat) contains a transcriptional fusion between a $\beta$-glucuronidase (GUS) sequence and the fulllength monomer satellite sequence. In p35GUS:Sat, the sequence postulated to be optimal for the formation of ribozyme structures, which is required for efficient plus-strand cleavage of the native CYDV satRNA, does not occur in the regions flanking the satellite sequence (Fig. 1B). This fusion gene was therefore not expected to produce self-cleaving transcript and hence monomeric satRNA.

Tobacco plants transformed with p35Sat produced modest levels of the expected 322-nt monomeric form of CYDV satRNA (Fig. 2, lanes 3 and 4). The larger bands in these samples presumably represent various partial-cleavage products of the primary transcript. When the T1 progeny of transgenic p35Sat plants was infected with satRNA-free potato leafroll virus (PLRV), which belongs to the same luteovirus family subgroup as CYDV (Wang et al., 1998; Mayo \& D'Arcy, 1999), large amounts of satRNA in mono- and polymeric forms were detected (Fig. 2, lanes 6 and 7). This indicates that the transgene-derived satRNA was being replicated in a rolling circle manner by PLRV.

Surprisingly, we found that the p35GUS:Sat plants also gave high levels of satRNA replication when infected with PLRV (Fig. 2, lane 5). They must have produced RNA molecules, despite lacking intact selfcleavage domains, that could be amplified by PLRV into functional satRNA, perhaps arising by nonspecific degradation of the GUS:Sat RNA.

\section{CYDV satRNA replication correlated with dense DNA methylation in the satellite sequence of the GUS:Sat fusion transgene}

Four independent p35SGUS:Sat transgenic lines (GS1, GS2, GS3, and GS4) were used to study the effect of satellite replication on transgene methylation. Southern analysis (e.g., Fig. 4A) and selectable marker inheritance showed that the T1 siblings within each line inherited identical transgene complements (two copies for lines GS1 [data not shown] and GS3, two to three copies for line GS2, and three to four copies for line GS4) as single loci. The methylation of the transgenes was first examined in uninoculated or PLRV-infected, antibiotic-resistant T1 siblings of these lines using bisulphite sequencing. Bisulphite treatment converts unmethylated $\mathrm{C}$ residues in genomic DNA to $U$ residues,

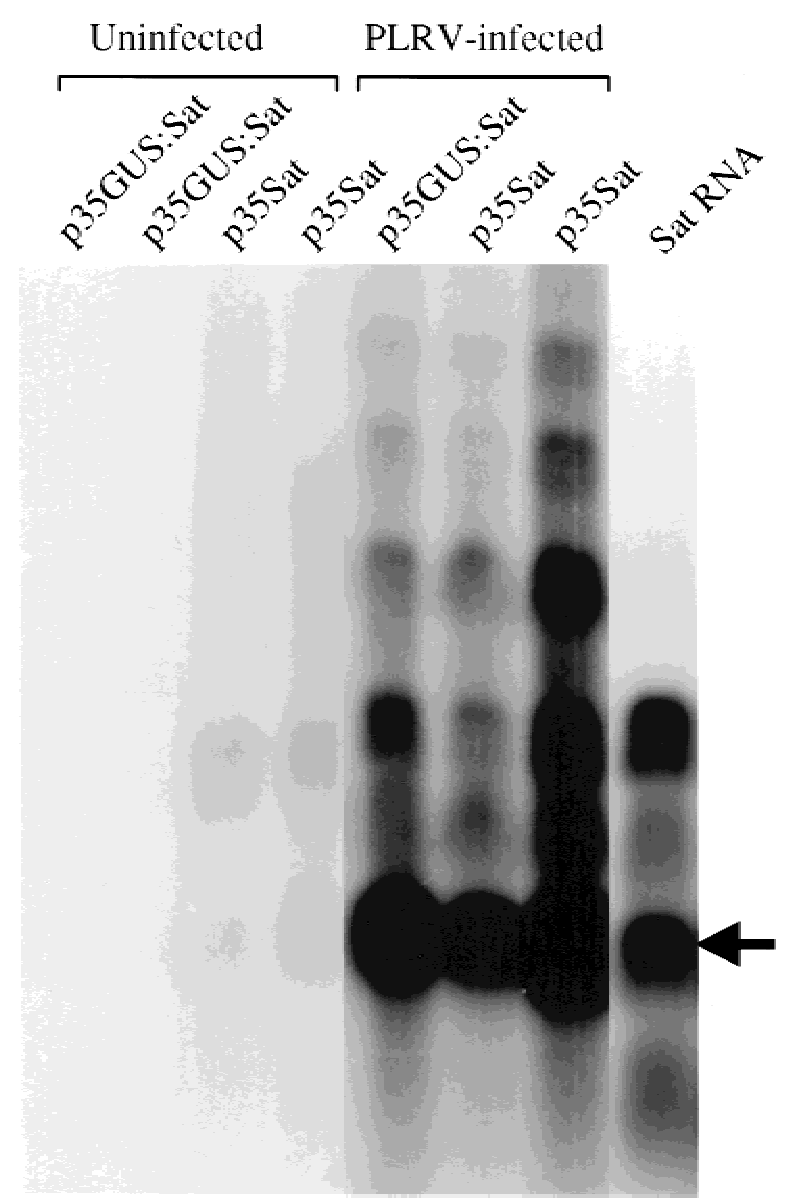

FIGURE 2. Evidence of expression of the monomeric form of CYDV satRNA in primary p35Sat transformants, and replication of the transgene-derived satRNA in primary p35Sat and p35GUS:Sat transformants by PLRV. Total RNA (30 $\mu \mathrm{g}$ each) was separated in $1.3 \%$ formaldehyde agarose gel, blotted to Hybond-N membrane, and hybridized with in vitro-transcribed, ${ }^{32} \mathrm{P}$-labeled, antisense CYDV satRNA. Sat RNA, in vitro sense transcript of the Sat3'-Sat-Sat5' fusion sequence in pGEM.Sat, mixed with $30 \mu \mathrm{g}$ total RNA from nontransgenic plant. The arrow indicates the monomeric form of CYDV satRNA.

but does not affect methylated $\mathrm{C}$ residues; thus cloning and sequencing the PCR amplification products from bisulphite-treated DNA detects the methylation status of each cytosine (Clark et al., 1994). The transgene DNA from uninfected p35GUS:Sat plants (Fig. 3A) had low levels of DNA methylation, of which all but one of the methylated cytosines were in the symmetrical CG or CNG context. In contrast, the satellite sequences of the transgenes in the PLRV-infected, satRNA-replicating, p35GUS:Sat plants were densely methylated (Fig. 3B). All of the 86 cytosines in the upper strand and 73 of the 75 cytosines in the lower strand within the satellite sequences were either fully or partially methylated. These included cytosines in both symmetric and nonsymmetric contexts, although those in the symmetrical contexts were methylated at higher frequencies $(85.2 \%$ on average) than in the nonsymmetrical contexts $(56.6 \%$ 
on average). The methylation was mostly restricted to the satellite sequences, with only a few cytosines in the immediate flanking sequences being methylated.

The satellite sequence in the p35SGUS:Sat transgene was analyzed by bisulphite sequencing in genomic DNA from PLRV-infected and uninfected plants of all four independent transgenic lines. The degree of methylation in individual PCR clones from uninfected plants ranged from 0 to $15 \%(6.0 \%$ on average). In contrast, every PCR clone from PLRV-infected plants had between 36 and $93 \%$ of its cytosines (symmetric and nonsymmetric sites) methylated. This suggests that the hypermethylation occurred in most if not all cells in the PLRV-infected, satRNA-replicating, plants.

To confirm these methylation results from a larger population of molecules, two approaches were taken. One approach used bisulphite conversion and PCR amplification, but replaced the cloning and sequencing with hybridization of the PCR product to a probe containing the original satellite sequence. The other used Southern analysis of the transgene DNA treated with the restriction enzyme McrBC, which digests only methylated DNA (Sutherland et al., 1992). With the first approach, the PCR products from all the uninfected p35SGUS:Sat plants and the control plasmid showed very low levels of hybridization with the original satellite sequence (Fig. 4B, lanes 2, 3, 4, and 8), indicating that most of the $C$ residues in the satellite sequence had been converted to $U$ residues by bisulphite treatment. In contrast, the PCR products from the infected plants gave strong hybridization signals (Fig. 4B, lanes 5-7), indicating that most of the cytosines in the satellite sequence of the transgenes were methylated and resistant to bisulphite conversion.

The second approach also confirmed the correlation between dense methylation of the satellite sequence in the p35SGUS:Sat transgenes and satellite replication. Genomic DNA from both PLRV-infected and uninfected p35GUS:Sat plants was treated with the restriction enzyme EcoRV, to release a 1.4-kb fragment that included the full-length satellite sequence (Fig. 1A), and with the enzyme McrBC. The DNA was then hybridized with the satellite sequence. As shown in Figure 4C, the McrBC-treated DNA from uninfected plants gave significant levels of hybridization signals (the decreased size of the hybridization band in comparison to untreated DNA might be due to partial digestion by McrBC), whereas that from the satRNA-replicating plants gave little or no hybridization signals. This demonstrates that the latter had much higher levels of methylation in the satellite sequence than the former.

\section{A small satellite RNA species was detected in satRNA-replicating plants}

A small, approximately 25-nt RNA has been found to be correlated with PTGS in plants (Hamilton \& Baul- combe, 1999). To examine whether such RNA species exist in satRNA-replicating plants, RNA was isolated from the same virus-infected and uninfected p35GUS: Sat plants shown in Figure 4B, separated in polyacrylamide gel, and hybridized with sense (Fig. 5A) or antisense (Fig. 5B) satellite probes. Small satellitederived RNAs of both sense and antisense orientation of $\sim 22 \mathrm{nt}$ were detected in all three plants that contained replicating satRNA, but not in the three uninfected plants. Probing the filter for GUS sequences gave no detectable signal for RNAs in this size range (data not shown).

\section{Accumulation of truncated RNA in p35GUS:Sat plants was associated with satRNA replication}

To examine the effect of satRNA replication on the expression of the p35GUS:Sat transgene, total RNA was isolated from PLRV-infected or uninfected p35GUS:Sat plants and analyzed by northern blot hybridization. Infected and uninfected tobacco plants expressing a GUS gene without the CYDV satellite sequence were included as controls. In the p35GUS:Sat plants, the levels of full-length GUS:Sat transcript were, on average, significantly lower in PLRV-infected than in uninfected plants (Fig. 6, lanes 1-8 versus lanes 13-20). Curiously, a reduction of transcription upon PLRV infection was also apparent in the control GUS plants, perhaps as part of a general gene down-regulation due to virus infection. However, the reduction of GUS transcript level (Table 1) was greater in the p35GUS:Sat plants (1.9fold) than in the GUS plants (0.8-fold). Despite the presence of the satellite sequence in its $3^{\prime}$ region, the p35GUS:Sat fusion gene still gave moderate levels of GUS activity. The GUS expression levels determined by fluorometric assay (Jefferson et al., 1987) in infected and uninfected p35GUS:Sat and GUS plants correlated with the abundance of full-length GUScontaining transcript (Table 1).

In the p35GUS:Sat plants in which the satRNA was replicating, we observed a substantial amount of lessthan-full-length GUS:Sat transcript (Fig. 6, lanes 1-7). Surprisingly, the majority of this shorter transcript appeared to be of a similar size, forming a relatively unique hybridizing band (band 2). This band could not be seen for the p35GUS:Sat plants (Fig. 6, lanes 13-20) not infected with PLRV or plant GS2-3 (Fig. 6, lane 8), which was infected with PLRV but showed no detectable satRNA replication (it is possible that satRNA replication occurred in this plant but at an undetectable level at the time of assay). RNA band 2 was also absent from the control GUS plants, which instead contained a number of truncated signals with smaller sizes. A further northern blot analysis showed that these smaller bands were common to all the p35GUS:Sat and control GUS plants with or without PLRV infection. The size of band 2 (approximately $1.9 \mathrm{~kb}$ ) appears to 

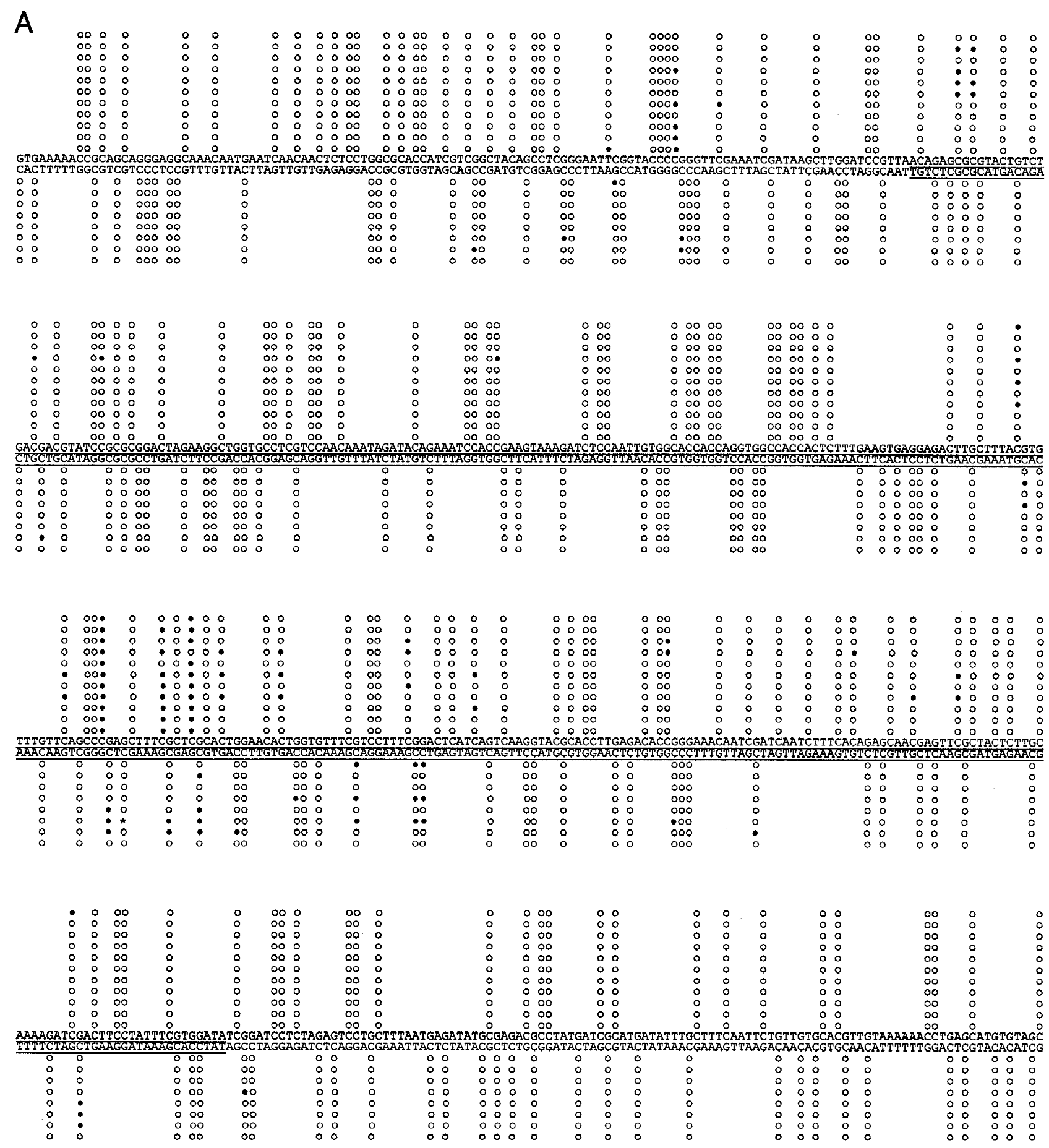

FIGURE 3. Methylation status of CYDV satellite sequence and its flanking GUS-polylinker and Ocs3' sequences in transgenic p35GUS:Sat plants without (A, plants GS1-8 or GS1-10) or with (B, plants GS1-1 or GS2-2) replicating CYDV satRNA (infected with PLRV for 10 weeks). The empty circles indicate unmethylated cytosine residues, the filled circles the methylated $\mathrm{Cs}$ at symmetric (CG or CNG) sites, and the star symbols the methylated Cs at nonsymmetric sites. The number of circles or star symbols in each column indicates the number of sequenced DNA molecules, and the circles or star symbols in each line indicate the methylation status of an individual molecule. The satellite sequence is underlined. ( Figure continues on facing page.)

be close to that expected for a full-length GUS transcript without the additional sequences from the satRNA and the transcribed region of the Ocs terminator. This suggests that truncation had occurred around the GUS: Sat fusion site.

\section{The $3^{\prime}$ ends of the truncated RNAs coincided with the $5^{\prime}$ region of the satellite sequence}

To examine if RNA truncation in satRNA-replicating p35GUS:Sat plants indeed occurred around the GUS: 
B

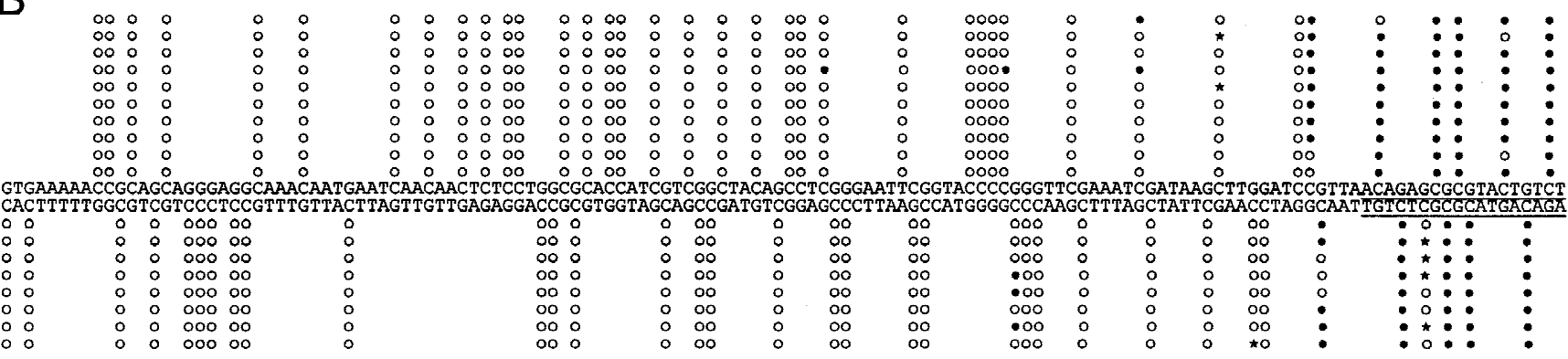
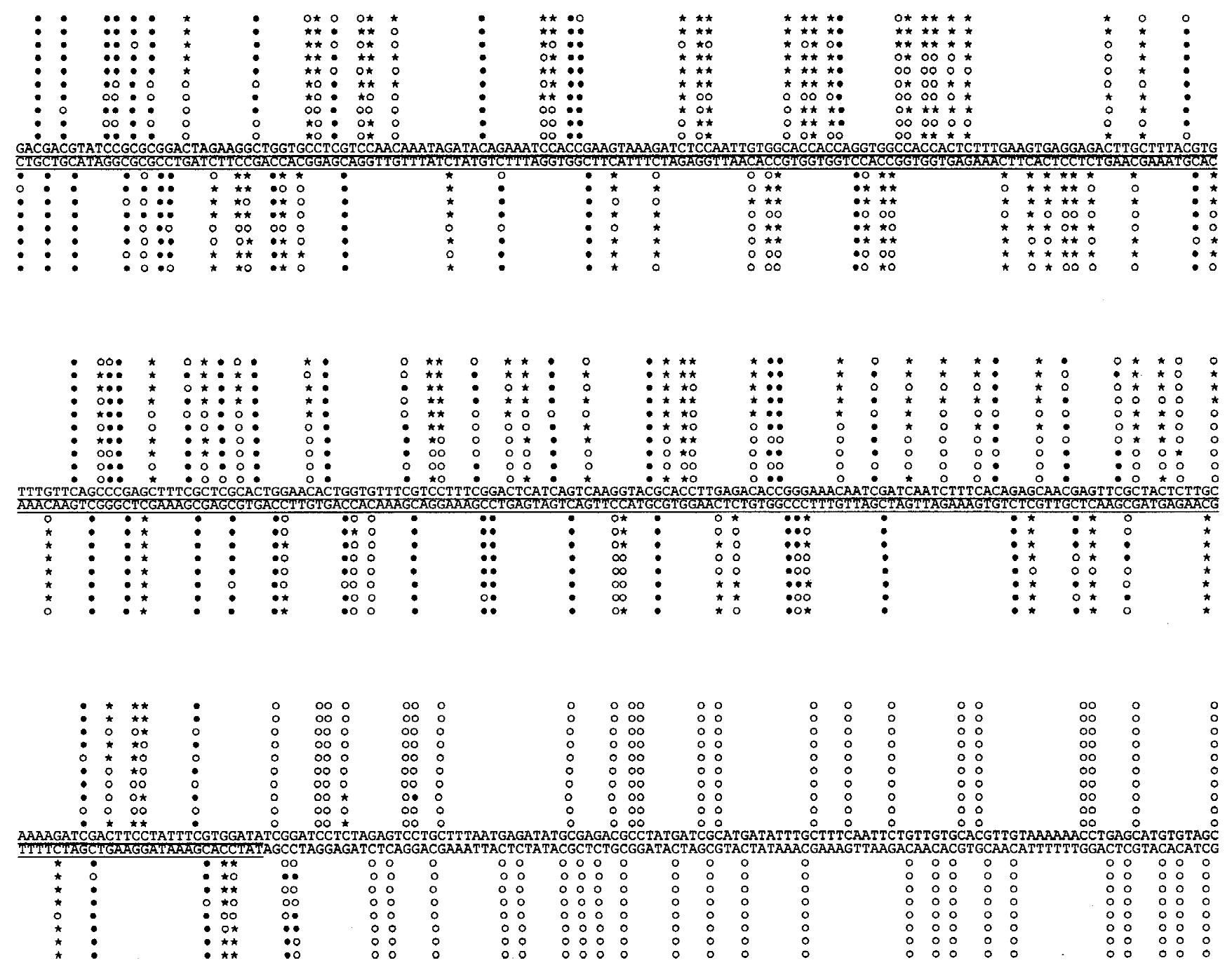

FIGURE 3. Continued.

Sat fusion area, RNA from the infected plants GS1-2, GS1-5, and GS2-1 and the uninfected plant GS2-4 (Fig. 6, lanes 2, 5, 6, and 18) and from several other infected or uninfected plants of the transgenic lines GS1, GS2, GS3, and GS4 was analyzed by RNAoligonucleotide ligation and subsequent RT-PCR (Fig. 7A,B). The GUS-specific primer used in the RTPCR corresponds to the nucleotides around $330 \mathrm{bp}$ upstream of the GUS/satellite junction in the p35GUS: sat transgene (Fig. 7C). Therefore, the RT-PCR products should be approximately $350 \mathrm{bp}$ (including the two primers) in size if the truncation of RNA occurs around the fusion site between the GUS and the satellite sequences, and approximately $800 \mathrm{bp}$ for the full-length transcript. As predicted, two major RT-PCR products were detected from the satRNA-replicating plants, one around $340 \mathrm{bp}$ and the other around 700-900 bp (Fig. 7A). The smearing of the full-length RNA band 
A
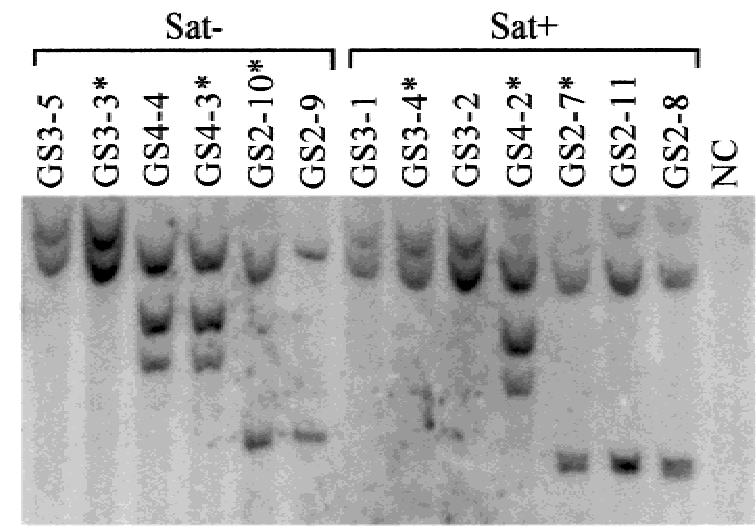

B

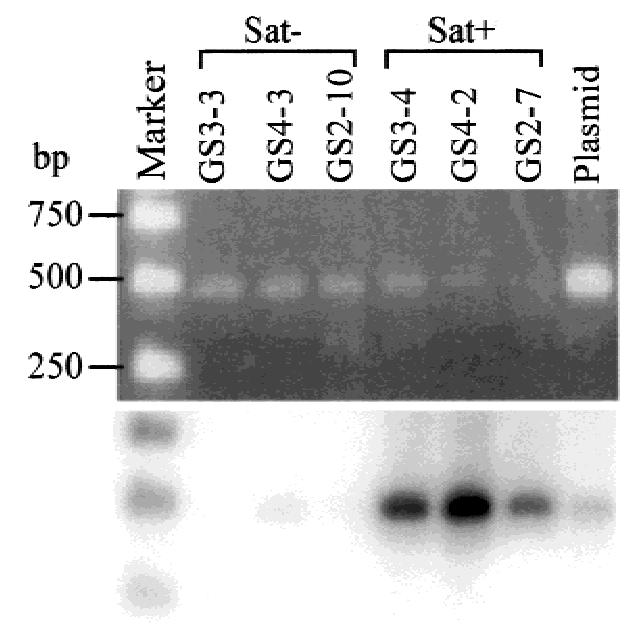

C

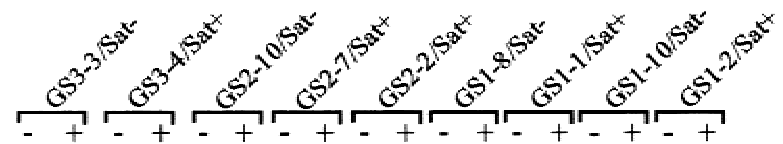

$\sin =$

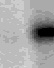

FIGURE 4. A: Transgene copy number analysis of $\mathrm{T} 1$ progeny of p35GUS:Sat lines GS2, GS3, and GS4 infected (for 17 weeks) with PLRV (Sat+) or uninfected (Sat-). Genomic DNA (20 $\mu \mathrm{g}$ each) was digested with HindIII, separated in $1 \%$ agarose gel, blotted onto Hybond-N+ membrane, and hybridized with ${ }^{32} \mathrm{P}$-labeled Ocs3' sequence. The asterisks indicate the plants that were analyzed in $\mathbf{B}$, in which the same DNA used in A was treated with bisulphite, the satellite and 100 -bp flanking sequences were amplified by PCR, and the PCR products separated in $1.5 \%$ agarose gel (upper panel), blotted onto Hybond-N+ membrane, and hybridized with the satellite sequence (lower panel). C: Methylation analysis using McrBC digestion. Genomic DNA isolated from plants uninfected (Sat-) or infected (Sat+) with PLRV for 17 weeks (GS3-4, GS2-7), 10 weeks (GS1-1, GS2-2) or 15 months (GS1-2) was digested with EcoRV in the presence $(+)$ or absence $(-)$ of the McrBC enzyme (New England Biolabs), separated in $1 \%$ agarose gel, blotted onto Hybond-N+ memebrane, and hybridized with the satellite sequence. NC: nontransgenic control. Marker: DNA size marker. Plasmid: plasmid DNA of p35GUS:Sat.

may reflect the different lengths of the poly $(A)$ tails in the RNA population. This result is in good agreement with that of the northern blot analysis (Fig. 6). The

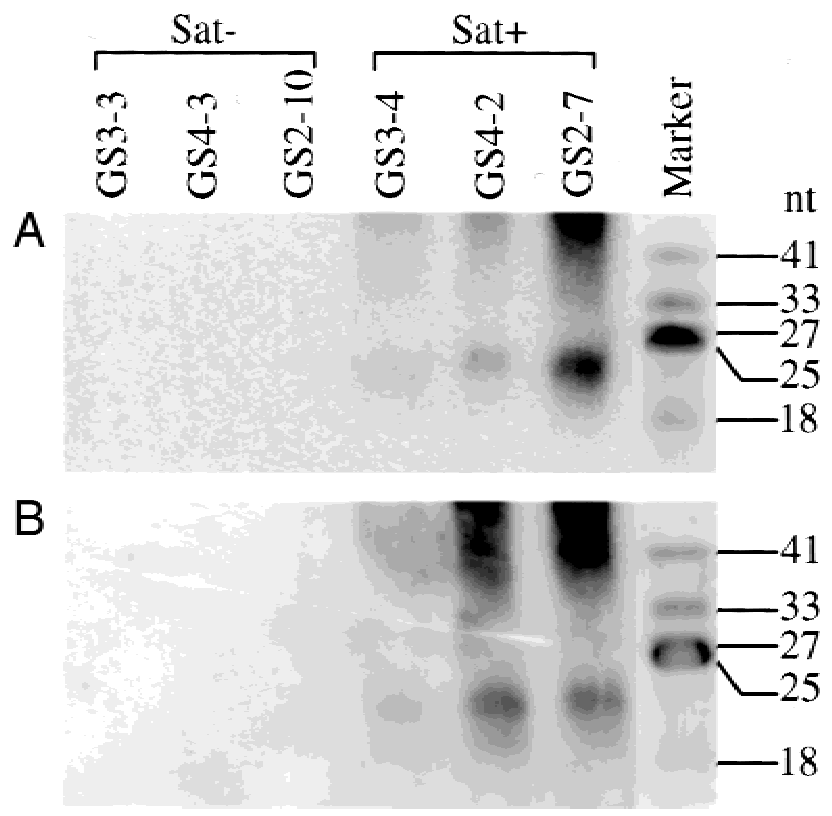

FIGURE 5. Detection of small satellite RNAs. Total RNA ( $20 \mu \mathrm{g}$ each), isolated using TRIzol from T1 p35GUS:Sat plants (same as those in Fig. 4B) uninfected (Sat-) or infected (Sat + ) with PLRV for 17 weeks, was separated in $15 \%$ denaturing polyacrylamide gel, blotted onto Hybond-N filter, and hybridized with in vitro-transcribed, ${ }^{32}$ P-labeled, sense (A) or antisense (B) satellite RNA. Marker: size markers comprised of DNA oligonucleotides.

uninfected p35GUS:Sat plant GS2-4 showed little signal around 340 bp (Fig. 7A,B), although when the primary RT-PCR products were reamplified by PCR using the same primers, bands with different sizes were observed in the PCR products for the uninfected as well as the infected plants (Fig. 7B).

To identify the exact $3^{\prime}$ ends of the truncated RNA molecules, the DNA (290-400 bp) around the $340 \mathrm{bp}$ band as shown in Figure 7A and $B$ was purified from the gel, cloned into pGEM-T Easy vector and sequenced. As shown in Figure $7 \mathrm{C}$, the majority (37 out of 40 ) of the truncated RNA molecules from the satRNA-replicating plant had $3^{\prime}$ ends that correspond to nucleotides within the first $65 \mathrm{bp}$ of the satellite sequence. Only two of the RT-PCR clones had been truncated outside the satellite sequence. None of the truncations was at the ribozyme cleavage site, indicating that they were not due to ribozyme-mediated selfcleavage of the full-length transcript. An attempt to identify the $3^{\prime}$ ends of the low-level truncated RNAs from uninfected plants as shown in Figure $7 \mathrm{~B}$ was unsuccessful because cloning of the RT-PCR products failed to yield GUS sequence-containing clones.

\section{RNA truncation was independent of the levels of DNA methylation in the satellite sequence}

To examine whether the RNA truncation was due to methylation of the satellite sequence, we analyzed the 


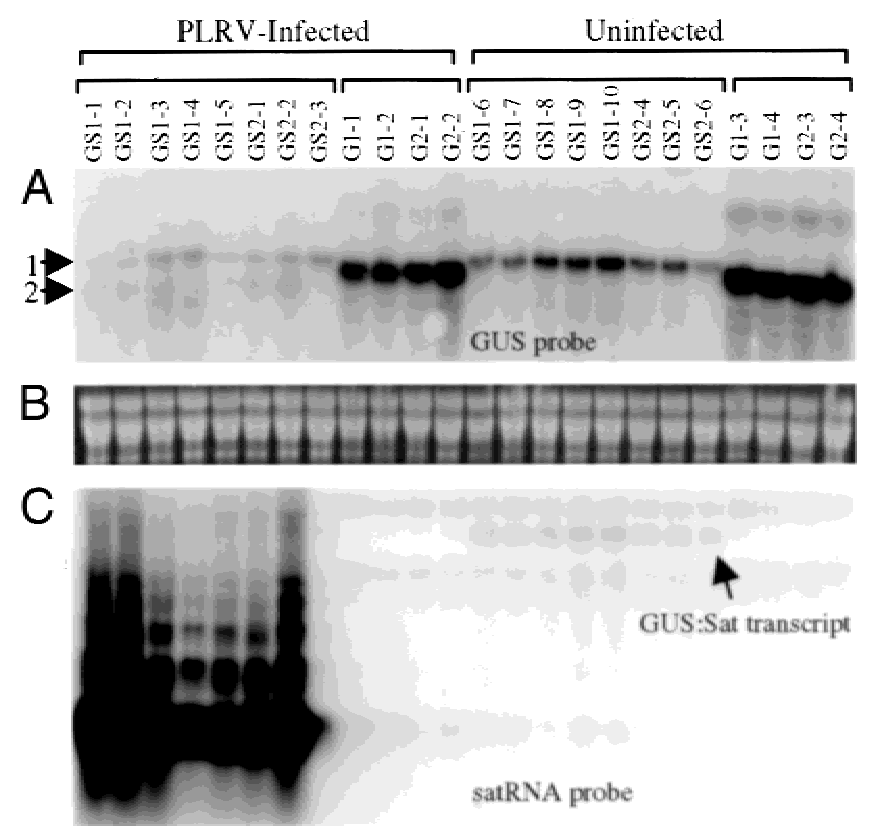

FIGURE 6. Northern blot analysis of T1 p35GUS:Sat (GS) or control GUS (G) plants uninfected or infected with PLRV (for 10 weeks). Total RNA (25 $\mu \mathrm{g}$ each) was separated in $1.3 \%$ formaldehydeagarose gel, blotted to Hybond-N membrane, and hybridized with in vitro-transcribed, ${ }^{32} \mathrm{P}$-labeled, antisense GUS RNA (A) or CYDV satRNA (C). B: RNA loading control for $\mathbf{A}$. The two arrows show the full-length GUS:sat RNA (1) and the truncated RNA (2) bands.

RNA isolated from p35GUS:Sat plants infected with PLRV for over 13 months (Fig. 8A-C, lanes 1-4) or for 5 weeks (Fig. 8A-C, lanes $5-10$ ). SatRNA replication was evident in the plants 13 months after infection (Fig. 8C, lanes 1-4), but the levels of satRNA were generally low, probably because the tissue was relatively old and unfavorable for helper virus (PLRV) replication. Plants GS3-2 and GS4-1, infected for 5 weeks, showed very high levels of satRNA replication (Fig. 8C, lanes 6 and 7). The other plants infected at that time had low or undetectable levels of satRNA, but the satRNA replication reached high levels similar to that seen in GS3-2 and GS4-1 when analyzed 17 weeks after PLRV infection (data not shown). As shown in Figure $8 \mathrm{~A}$ and $\mathrm{C}$, truncated RNA was clearly detected in the two plants that had high levels of satRNA replication (lanes 6 and 7). None of the other infected plants showed the truncated RNA signal, despite the presence of replicating satRNA in most of these plants. Interestingly, the level of full-length GUS:Sat RNA in the two plants with truncated RNA (i.e., GS3-2 and GS4-1) was not significantly different from the other plants in Figure 8A that had little or no replicating satRNA and showed no truncated RNA.

High levels of satRNA replication could lead to high levels of DNA methylation in the satellite sequence, which could account for the presence of truncated RNA production. We investigated this by examining the methylation status of the DNA from plant GS2-2 and from plants GS3-2 and GS4-1 through hybridization of PCR products amplified from bisulphite-treated DNA with the satellite sequence (Fig. 8D). Plant GS2-2 showed a high level of DNA methylation (lane 1) despite the low level of satRNA replication. Sequencing of the PCR products indicated that the levels of methylation in the satellite sequence was comparable to those shown in Figure 3B (50\% to $76 \%$ of the cytosines in each molecule were methylated). In contrast, plants GS3-2 and GS4-1, which had very high levels of satRNA replication, showed very low levels of DNA methylation (Fig. 8D, lanes 2 and 3). Taken together, these results indicate that widespread, dense DNA methylation induced by satRNA did not occur immediately upon satRNA replication, and suggest that this methylation of the satellite sequence is not the prime cause of the RNA truncation.

\section{DISCUSSION}

RNA-directed DNA methylation has been demonstrated with potato spindle tuber viroid (Wassenegger et al., 1994) and plant poty- and potexviruses (Jones et al., 1998, 1999). Here we show that the satellite RNA of cereal yellow dwarf luteovirus, when replicating in plant cells, is also capable of directing high levels of de novo DNA methylation. The methylation is highly sequence specific, being restricted mostly to the satellite sequence of the GUS:Sat fusion transgene. Our results thus provide a new example of RdDM and further evidence of the general existence of RdDM in plants. In addition, we present evidence that $\sim 22$-nt sense and antisense RNAs are associated with the RdDM-directing satRNA and that DNA methylation in the coding sequence does not cause RNA truncation. This provides insights into the induction and spread of RdDM, and into its possible biological role in plants.

\section{Induction of RdDM}

All three types of RNA species (virus, viroid, and now satellite), with the proven ability to direct de novo DNA methylation, replicate or are replicated in the plant. Perhaps replication is needed to produce sufficient levels of RNA for efficient RdDM. Alternatively, the doublestranded nature of the RNA, which is expected to exist during the RNA replication process, is the effective inducer of RdDM, as suggested by Kooter et al. (1999). This latter concept is supported by Mette et al. (1999) who showed that transcription of an inverted repeat locus encoding a nopaline synthase promoter (NOSpro), to presumably produce a self-complementary transcript, appeared to direct methylation of other copies of the NOSpro sequence in the genome. It is also con- 
TABLE 1. Comparison of full-length transgene RNA levels and GUS activities in PLRV infected (PLRV+) and uninfected (PLRV-) plants

\begin{tabular}{|c|c|c|c|c|c|}
\hline \multirow{2}{*}{$\begin{array}{l}\text { Virus } \\
\text { infection }\end{array}$} & \multirow[b]{2}{*}{ Plants } & \multirow{2}{*}{$\begin{array}{l}\text { Relative } \\
\text { GUS } \\
\text { activity }^{\mathrm{a}}\end{array}$} & \multirow{2}{*}{$\begin{array}{c}\text { Relative } \\
\text { abundance of } \\
\text { full-length } \mathrm{RNA} \mathrm{A}^{\mathrm{b}}\end{array}$} & \multicolumn{2}{|c|}{ Average values } \\
\hline & & & & GUS activity & RNA abundance \\
\hline \multirow[t]{12}{*}{ PLRV+ } & GS1-1 & 0.87 & 1.4 & $0.50(0.11)^{c}$ & $3.2(0.4)$ \\
\hline & GS1-2 & 1.10 & 2.3 & & \\
\hline & GS1-3 & 0.32 & 4.1 & & \\
\hline & GS1-4 & 0.16 & 3.9 & & \\
\hline & GS1-5 & 0.27 & 2.1 & & \\
\hline & GS2-1 & 0.25 & 2.6 & & \\
\hline & GS2-2 & 0.46 & 3.8 & & \\
\hline & GS2-3 & 0.54 & 5.2 & & \\
\hline & G1-1 & 5.75 & 17 & $5.91(0.41)$ & $23(3)$ \\
\hline & G1-2 & 4.94 & 19 & & \\
\hline & G2-1 & 5.73 & 22 & & \\
\hline & G2-2 & 7.23 & 35 & & \\
\hline \multirow[t]{12}{*}{ PLRV- } & GS1-6 & 1.72 & 6.4 & $1.18(0.19)$ & $9.3(0.9)$ \\
\hline & GS1-7 & 1.13 & 6.8 & & \\
\hline & GS1-8 & 0.93 & 11.0 & & \\
\hline & GS1-9 & 1.03 & 11.9 & & \\
\hline & GS1-10 & 2.32 & 14.1 & & \\
\hline & GS2-4 & 0.95 & 8.7 & & \\
\hline & GS2-5 & 0.65 & 9.2 & & \\
\hline & GS2-6 & 0.72 & 6.3 & & \\
\hline & GS1-3 & 9.67 & 43 & $8.88(0.64)$ & $41(4)$ \\
\hline & GS1-4 & 9.15 & 46 & & \\
\hline & GS2-3 & 9.99 & 46 & & \\
\hline & GS2-4 & 6.73 & 28 & & \\
\hline
\end{tabular}

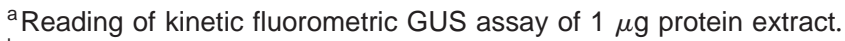

${ }^{b}$ Relative signal intensity of the full-length hybridization bands in Figure 6 calculated using the ImageQuant computer program.

cThe figures in brackets are standard errors.
}

sistent with the results of Dalmay et al. (2000) showing that a release of transgene methylation in Arabidopsis plants deficient in PTGS and RNA-dependent RNA polymerase (RdRP) correlated with the proposed inability to produce dsRNA to mediate PTGS.

\section{RdDM signal and spread}

PLRV, the helper virus for CYDV satRNA in tobacco, replicates only in the cytoplasm of phloem and phloemassociated cells (Shepardson et al., 1980; Taliansky \& Barker, 1999) so the amplification of CYDV satRNA is expected to be similarly restricted. However, our results from a range of analyses suggest that the satellite sequence of the p35GUS:Sat transgene was methylated in most (if not all) cells of the satRNA-replicating plants. This suggests that the satRNAs, unaided by the helper virus, or secondary RNA signals produced from the satRNA were capable of moving from cell to cell and entering nuclei to interact with homologous DNA sequences. The existence of such a diffusible signal for RdDM has been suggested by previous results with PSTVd and viruses. PSTVd-directed DNA methylation was found to occur in the majority of leaf cells although a large portion of them was expected to be viroid-free (Pélissier et al., 1999) and there is evidence that potyvirus-directed de novo DNA methylation can occur in cells of shoot meristems in which the potyvirus has not replicated (Jones et al., 1998).

What is the signal molecule? The presence of $\sim 25$-nt RNAs has been found to be perfectly correlated with posttranscriptional gene silencing in plants and has been proposed to be a possible component of the systemic signal for this type of silencing (Hamilton \& Baulcombe, 1999). In our study, small, $\sim 22-n t$, sense and antisense satellite-derived RNAs could be readily detected in plants showing PLRV-replicated satRNA and heavily methylated satellite transgene sequences, but not in uninfected plants. This makes these small RNAs likely candidates as signal molecules for spreading and directing RdDM. They may also play a similar role in directing sequence-specific RNA degradation as 21-23 nt RNAs have been shown to mediate RNAi (or dsRNAinduced mRNA degradation) in Drosophila (Zamore et al., 2000), suggesting that the small RNAs are directing both PTGS and RdDM in plants. 

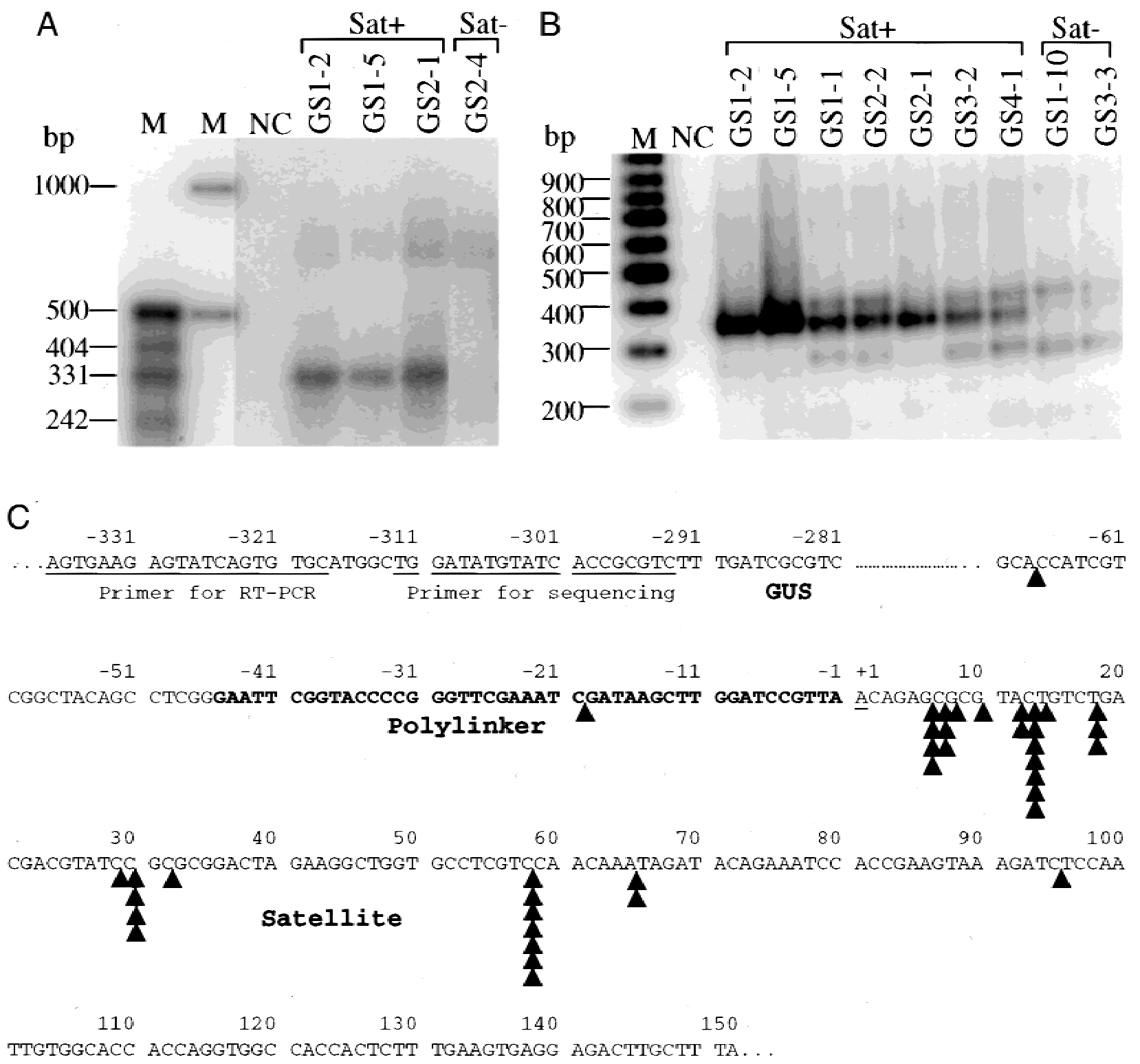

FIGURE 7. Analysis of $3^{\prime}$ ends of truncated p35GUS:Sat RNA from T1 plants uninfected (Sat - ) or infected (Sat+) with PLRV for 10 weeks (GS1 and GS2 plants, same as those in Fig. 6) or 5 weeks (GS3-2 and GS4-1, same as those in Fig. 8). Portions of the initial RT-PCR (A) or secondary PCR (B) reactions were separated in 1.5\% agarose gel, blotted onto Hybond- $\mathrm{N}^{+}$filter, and hybridized with ${ }^{32} \mathrm{P}$-labeled GUS sequence. NC: nontransgenic control. M: DNA size markers. C: Sequencing analysis of RNA-oligonucleotide ligation/RT-PCR products. The arrows indicate the $3^{\prime}$ termini of truncated RNA sequences, and each arrow represents one RT-PCR clone that was sequenced. The bold letters indicate the polylinker region between the GUS and the satellite sequences.

\section{Truncation of transgene transcripts associated with satRNA replication}

Replication of CYDV satRNA was associated with the accumulation of truncated GUS:Sat RNA, and the truncation occurred within the $5^{\prime}$ region of the satellite sequence. Previous studies with Neurospora (Rountree \& Selker, 1997) and Ascobolus (Barry et al., 1993) suggest that DNA methylation may block transcription elongation, which could lead to the production of truncated RNA. However, our results show that the presence of the truncated GUS:Sat RNA was independent of the degree of DNA methylation in the satellite sequence. This makes it unlikely that methylation was responsible for the production of the truncated RNA observed in the satRNA-replicating plants. The results favor an involvement of direct RNA/RNA or RNA/DNA interactions in the production of truncated RNA. The truncation of GUS:Sat RNAs could be due to specific removal of the satellite region from mature or primary GUS:Sat transcripts through RNAi-like degradation. In Drosophila, RNAi-mediated cleavage of mRNA occurs only within the region of identity to the inducer dsRNA (Zamore et al., 2000). However, in the plants where truncated 


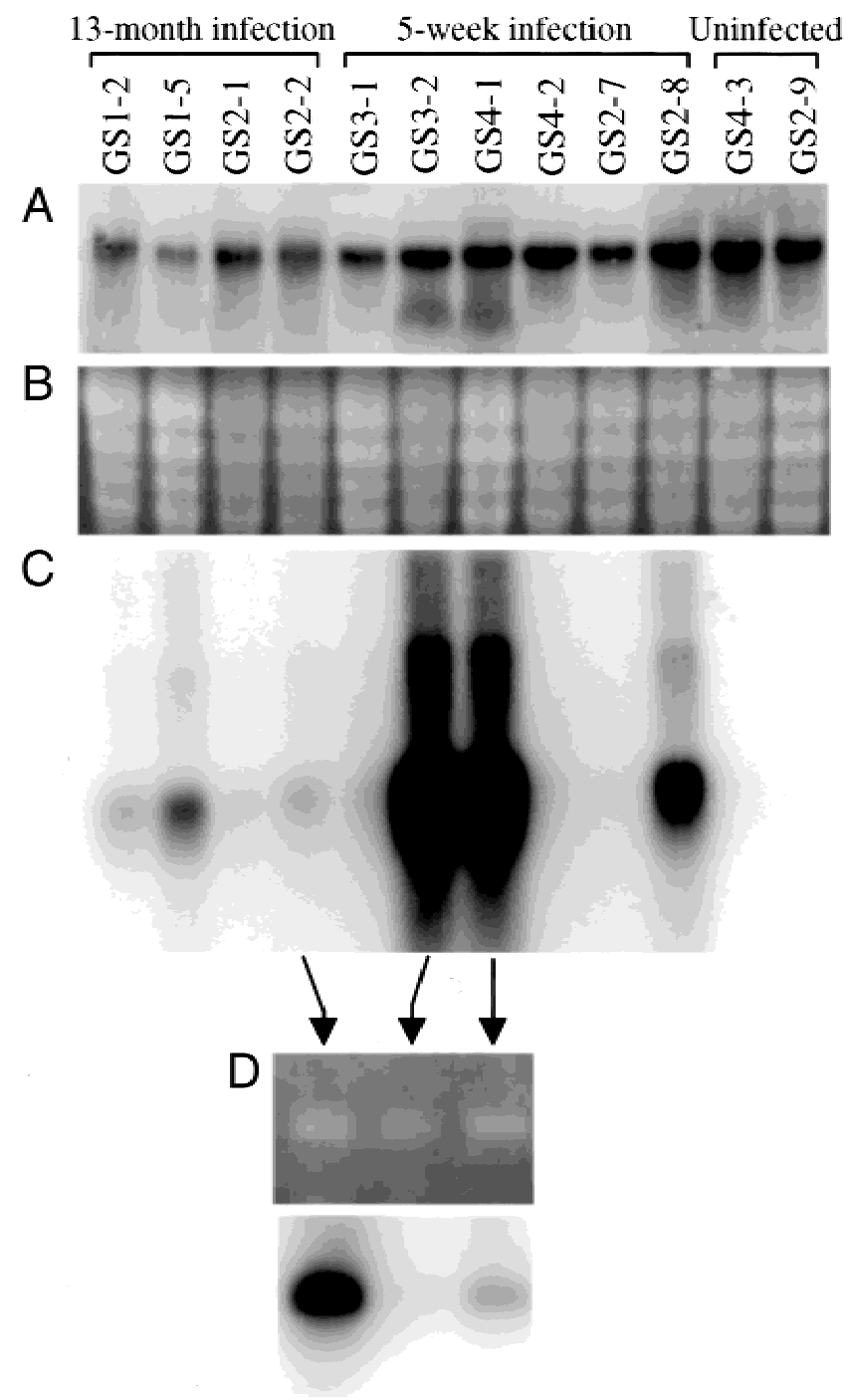

FIGURE 8. RNA truncation versus satRNA replication and DNA methylation. Total RNA (30 $\mu \mathrm{g}$ each) isolated from T1 p35GUS:Sat plants uninfected or infected with PLRV for 13 months or 5 weeks was separated in $1.2 \%$ formaldehyde agarose gel, blotted onto Hybond-N membrane, and hybridized with in vitro-transcribed, ${ }^{32} \mathrm{P}$ labeled antisense GUS (A) or satellite (C) RNA. B: loading control. D: Genomic DNA from plants GS2-2, GS3-2, and GS4-1 (as indicated by arrowheaded lines) was treated with bisulphite, the satellite sequence and 100 bp flanking sequences were amplified by PCR, the products separated in $1.5 \%$ agarose gel (upper panel), blotted onto Hybond-N+ membrane, and hybridized with the satellite sequence (lower panel).

RNA occurred, substantial amounts of full-length GUS: Sat RNA persisted, suggesting that, if RNAi-mediated degradation was operational, it was relatively inefficient.

Alternatively, the truncated GUS:Sat RNA could have been produced by transcription that was prematurely terminated by the formation of RNA/DNA triplexes. Triplex-forming oligonucleotides have been shown to inhibit transcription elongation in animal cells (Faria et al., 2000). The satellite-derived $\sim 22$ nt RNAs in the PLRVinfected p35GUS:sat plants may similarly form triplexes with the homologous DNA sequences in the transgene and inhibit transcription elongation. The coexistence of both full-length GUS:Sat RNA and truncated RNA, that we observed, might have been due to different levels of the satRNA and the resultant transcription-terminating 22-nt RNAs in different cell types; the levels of these RNAs could be relatively high in the phloem and phloemassociated cells where the virus replicates, leading to significant levels of transcription termination and truncated RNA, whereas the RNAs that spread into the uninfected cells could be at insufficient concentrations to cause premature termination. Pooling the transcripts from all the cell types, as we did by extracting from whole-tissue samples, would then be expected to give a population of both truncated and full-length transcripts.

\section{The biological role of RdDM}

The independence of RNA truncation on DNA methylation observed in this study is consistent with our previous finding that GUS gene silencing by a dsRNAencoding inverted-repeat transgene is associated with increased DNA methylation in the GUS sequence but is not reversed by demethylation treatment (Wang \& Waterhouse, 2000). In both cases, the hypermethylation appears to be a footprint of dsRNA-mediated PTGS, but does not contribute to the reduction in RNA levels. This suggests that, although PTGS and RdDM are likely to be induced by the same dsRNA, they may have distinct biological roles. It has been suggested that PTGS is a natural mechanism developed by plants to fight against viral infection (Covey et al., 1997; Kooter et al., 1999; Waterhouse et al., 1999). DNA methylation, on the other hand, has been suggested to play a role in plant defense against selfish DNA (i.e., transposon elements) by silencing the transposons through methylation-induced chromatin condensation (Ashraf \& Ip, 1998; Kooter et al., 1999). It has been recently found that, in Caenorhabditis elegans, mutations of several genes involved in RNAi can cause reactivation of transposons (Tabara et al., 1999). This indicates that dsRNA is involved in both RNA degradation and transposon silencing. Our result suggests that this may also be the case in plants; dsRNA confers viral resistance by triggering PTGS against viral RNA, while it can silence the transposons by inducing RdDM in the target sequences.

\section{MATERIALS AND METHODS}

\section{Plasmid construction}

The self-cleavable CYDV satellite sequence in p35Sat was constructed as follows: the $5^{\prime}$ half, the $3^{\prime}$ half, and the fulllength satellite sequences were amplified by PCR from a cDNA clone (Miller et al., 1991) using the following three combinations of primers, respectively: 5'-CGCGGATCCGTT AACAGAGCGCGTACTGTCTG-3' (primer 1) and 5'-GCCG 
AGCTCAAGTCTCCTCACTTCAAAG-3' (primer 2), 5'-GCG CTGCAGCTTTACGTGTTTGTTCAGC-3' (primer 3) and 5' GCGGGATCCGATATCCACGAAATAGGAAGTCG (primer 4), and primer 1 and primer 4. The three PCR fragments were assembled together in the order of the $3^{\prime}$ half, the full-length, and the $5^{\prime}$ half sequences through ligations between the EcoRV and Hpal sites introduced in primers 1 and 4 to form pGEM.Sat. This fusion sequence mimics the native multimeric form of the plus-strand CYDV satRNA and re-creates the ribozyme domain for plus-strand cleavage. The fusion satellite sequence in pGEM.Sat was excised with HindIII/ EcoRI, treated with Klenow polymerase, and cloned into the Smal site of pART7 (Gleave, 1992), forming p35Sat. To make the GUS:Sat fusion gene, the CYDV satellite sequence was amplified by PCR using the primers 1 and 4 shown above, and cloned along with a full-length GUS sequence into pART7. For Agrobacterium-mediated plant transformation, the constructs were inserted into the Notl site of pART27 (Gleave, 1992).

\section{Plant transformation}

Tobacco (Nicotiana tobaccum Wisconsin 38) was transformed essentially as described by Ellis et al. (1987).

\section{Northern blot hybridization}

Total RNA was isolated from tobacco tissue by the phenol extraction method essentially as described by de Vries et al. (1988) and quantified by UV spectrophotometry. RNA (20$30 \mu \mathrm{g}$ ) was separated in formaldehyde-agarose gel (Sambrook et al., 1989) and blotted to Hybond-N membrane (Amersham Life Science) using $10 \times$ SSC. The blot was hybridized with ${ }^{32} \mathrm{P}$-labeled RNA probes obtained by in vitro transcription using radioactive UTP from the respective sequences cloned into pGEM plasmids (Promega). Hybridization was performed at $55^{\circ} \mathrm{C}$ using buffer $\mathrm{B}$ as described in Promega's "Protocols and Application Guide."

\section{Detection of small sense and antisense satellite RNA}

Total RNA was isolated from approximately $50 \mathrm{mg}$ of tobacco leaf tissue using TRIzol (Gibco BRL) following the manufacturer's instructions (the overall small RNA detection protocol was kindly provided by Dr. Jan Kooter). Approximately $20 \mu \mathrm{g}$ of total RNA were separated in a $15 \%$ denaturing polyacrylamide gel, and then electroblotted and UV crosslinked onto Hybond-N membrane. To detect the small satRNA, the membrane was hybridized with sense or antisense satellite RNA probe transcribed from linearized pGEM.Sat plasmid. Hybridization was carried out at $45^{\circ} \mathrm{C}$ using the same solution for the northern hybridization described above.

\section{Virus infection}

Young plants grown from T1 seed of p35Sat and p35GUS:Sat tobacco were inoculated in a contained room with PLRV by placing approximately 10-20 viruliferous aphids onto each plant. After 2-5 days, the aphids were killed by application of systemic or contact insecticide, and the infected plants were then transferred to the glasshouse.

\section{Southern blot hybridization}

Total genomic DNA was isolated from tobacco leaves using a CTAB (cetyl triethylammonium bromide) method (Draper \& Scott, 1988). Approximately 10-20 $\mu \mathrm{g}$ DNA were digested with appropriate restriction enzymes, separated in agarose gel, blotted onto Hybond-N+ filter (Amersham Pharmacia Biotech) using $0.4 \mathrm{~N} \mathrm{NaOH}$ solution, and hybridized in formamide-containing buffer with appropriate sequences labeled with ${ }^{32} \mathrm{P}$.

\section{Bisulphite conversion and sequencing}

The methylation status of the cytosine residues was determined using the bisulphite conversion method described in Clark et al. (1994). Four micrograms DNA each from expanded leaves of satRNA-replicating or nonreplicating plants was treated with bisulphite and purified with the Wizard DNA Clean Up system (Promega). The DNA was resuspended in $100 \mu \mathrm{L}$ water, and $5-10 \mu \mathrm{L}$ was used in a $100-\mu \mathrm{L}$ PCR reaction. A hot-start PCR was performed using the Ampli Taq Gold $^{\mathrm{TM}}$ DNA polymerase (Perkin Elmer) with the following reaction profile: $12 \mathrm{~min}$ at $94^{\circ} \mathrm{C}$ followed by 10 cycles of $1 \mathrm{~min}$ at $94^{\circ} \mathrm{C}, 2: 30 \mathrm{~min}$ at $50^{\circ} \mathrm{C}, 1: 30 \mathrm{~min}$ at $72^{\circ} \mathrm{C}$, and 30 cycles with $1 \mathrm{~min}$ at $94^{\circ} \mathrm{C}, 1: 30 \mathrm{~min}$ at $55^{\circ} \mathrm{C}, 1: 30 \mathrm{~min}$ at $72^{\circ} \mathrm{C}$, with a final extension of $10 \mathrm{~min}$ at $72^{\circ} \mathrm{C}$. A $500-n t$ region of both the upper and the lower strands of DNA, which covers all of the satellite sequence along with $100 \mathrm{nt}$ flanking GUS-polylinker and Ocs3' sequences, was amplified using primers specially designed to preferentially hybridize with the bisulphite-converted molecules. The primers used were: 5' TAATAATTTTTTTGGTGTATTATTGTTGGT-3' (Gus-upperforward), 5' -TTAAAAACAAATATCATACAATCATAAACA-3' (Ocs3'-upper-reverse), 5'-ATAAAAAACCACAACAAAAAAA CAAACAATA-3' (Gus-lower-forward), and 5'-AGTTATATATG TTTAGGTTTTTTAT-3' (Ocs3'-lower-reverse). PCR products were purified using the Wizard PCR preps DNA Purification system (Promega) and cloned into pGem-T Easy vector (Promega). Plasmid DNA was prepared from Escherichia coli using Wizard Plus Minipreps DNA Purification System (Promega), and sequenced with an automatic DNA sequencer using the $\mathrm{M} 13$ reverse primer.

\section{RNA-oligonucleotide ligation-based RT-PCR (3' RACE) and DNA sequencing}

Ligation of the oligonucleotide 5' -CCACGTGAGCTCTGATT AAG-3' onto the $3^{\prime}$ termini of RNA was performed overnight at $16^{\circ} \mathrm{C}$ following the procedure described in Litière et al. (1999). Reverse transcription was performed at $42^{\circ} \mathrm{C}$ for $1 \mathrm{~h}$ using SupScript reverse transcriptase (GIBCO BRL) and a primer that was complementary to the above oligonucleotide. The subsequent PCR reaction was carried out using a GUSspecific primer, 5'-GACCCTGCAGTGAAGAGTATCAGTGT GC-3', and the primer used for reverse transcription, with the following reaction cycles: $3 \mathrm{~min}$ at $94^{\circ} \mathrm{C}, 1$ cycle; $45 \mathrm{~s}$ at 
$94^{\circ} \mathrm{C}, 45 \mathrm{~s}$ at $60^{\circ} \mathrm{C}, 1 \mathrm{~min}$ at $72^{\circ} \mathrm{C}, 10$ cycles; $45 \mathrm{~s}$ at $94^{\circ} \mathrm{C}$; $45 \mathrm{~s}$ at $56^{\circ} \mathrm{C}, 60 \mathrm{~s}$ at $72^{\circ} \mathrm{C}, 30$ cycles. A portion of the RTPCR product was separated in $1.5 \%$ agarose gel, blotted onto Hybond-N+ filter, and hybridized with ${ }^{32} \mathrm{P}$-labeled GUS probe. The RT-PCR product was reamplified by PCR with the same primers, separated in $1.5 \%$ agarose gel, and the DNA of approximately 290-400 bp was purified from the gel, cloned into pGEM-T Easy vector (Promega) and sequenced by the Big Dye Terminator method (PE Applied Biosystems) using the GUS-specific primer, 5'-TGGATATGTATCACCGCGTC-3'.

\section{ACKNOWLEDGMENTS}

We would like to thank Xiaomei Zhu, Geoff Ellacott, Judy Gaudron, and Roger Mummery for technical assistance, Brian Surin for suggestions on construction of pGEM.Sat, and Liz Dennis and Jake Jacobsen for their support. Financial support from Aventis is gratefully acknowledged.

Received July 6, 2000; returned for revision July 26, 2000; revised manuscript received October 17, 2000

\section{REFERENCES}

Ashraf SI, Ip YT. 1998. Transcriptional control: Repression by local chromatin modification. Curr Biol 8:R683-R686.

Barry C, Faugeron G, Rossignol J-L. 1993. Methylation induced premeiotically in Ascobolus: Coextension with DNA repeat lengths and effect on transcript elongation. Proc Natl Acad Sci USA 90: 4557-4561.

Clark SJ, Harrison J, Paul CL, Frommer M. 1994. High sensitivity mapping of methylated cytosines. Nucleic Acids Res 22:29902997.

Covey SN, Al-Kaff NS, Lángara A, Turner DS. 1997. Plants combat infection by gene silencing. Nature 385:781-782.

Dalmay T, Hamilton A, Rudd S, Angell S, Baulcombe DC. 2000. An RNA-dependent RNA polymerase gene in Arabidopsis is required for posttranscriptional gene silencing mediated by a transgene but not by a virus. Cell 101:543-553.

de Vries S, Hoge H, Bisseling T. 1988. Isolation of total and polysomal RNA from plant tissues. In: Gelvin SB, Schilperoort RA, Verma DPS, eds. Plant molecular biology manual. Dordrecht: Kluwer Academic Publishers. pp B6/1-B6/13.

Draper J, Scott R. 1988. The isolation of plant nucleic acids. In: Draper J, Scott R, Armitage P, Walden R, eds. Plant genetic transformation and gene expression-A laboratory manual. Oxford: The Alden Press. pp 199-236.

Ellis JG, Llewellyn DJ, Dennis ES, Peacock WJ. 1987. Maize Adh1 promoter sequences control anaerobic regulation: Addition of upstream promoter elements from constitutive genes is necessary for expression in tobacco. EMBO $J$ 6:11-16.

Faria M, Wood CD, Ferrouault L, Nelson JS, Winter A, White MRH, Hélène C, Giovannangeli C. 2000. Targeted inhibition of transcription elongation in cells mediated by triplex-forming oligonucleotides. Proc Natl Acad Sci USA 97:3862-3867.

Gleave AP. 1992. A versatile binary vector system with a T-DNA organizational structure conducive to efficient integration of cloned DNA into the plant genome. Plant Mol Biol 20:1203-1207.

Hamilton AJ, Baulcombe DC. 1999. A species of small antisense RNA in posttranscriptional gene silencing in plants. Science 286:950-952.

Jefferson RA, Kavanagh TA, Bevan MW. 1987. GUS fusion: $\beta$-glucuronidase as a sensitive and versatile gene fusion marker in higher plants. EMBO J 6:3901-3907.

Jones AL, Thomas CL, Maule AJ. 1998. De novo methylation and co-suppression induced by a cytoplasmically replicating plant RNA virus. EMBO J 17:6385-6393.

Jones L, Hamilton AJ, Voinnet O, Thomas CL, Maule AJ, Baulcombe
DC. 1999. RNA-DNA interactions and DNA methylation in posttranscriptional gene silencing. Plant Cell 11:2291-2301.

Jorgensen RA, Atkinson RG, Forster RLS, Lucas WJ. 1998. An RNAbased information superhighway in plants. Science 279:14861487.

Kooter JM, Matzke MA, Meyer P. 1999. Listening to the silent genes: Transgene silencing, gene regulation and pathogen control. Trends Plant Sci 4:340-347.

Litière K, van Eldik GJ, Jacobs JJMR, van Montagu M, Cornelissen M. 1999. Posttranscriptional gene silencing of gn1 in tobacco triggers accumulation of truncated gn1-derived RNA species. RNA 5:1364-1373.

Luff B, Pawlowski L, Bender J. 1999. An inverted repeat triggers cytosine methylation of identical sequences in Arabidopsis. Mol Cell 3:505-511.

Mayo MA, D’Arcy CJD. 1999. Family Luteoviridae: A reclassification of luteoviruses. In: Smith HG, Barker H, eds. The Luteoviridae. Wallingford, CT: CABI Publishing. pp 15-22.

Mette MF, van der Winden J, Matzke MA, Matzke AJM. 1999. Production of aberrant promoter transcripts contributes to methylation and silencing of unlinked homologous promoters in trans. EMBO J 18:241-248.

Miller WA, Hercus T, Waterhouse PM, Gerlach WL. 1991. A satellite RNA of barley yellow dwarf virus contains a novel hammerhead structure in the self-cleavage domain. Virology 183:711-720.

Pélissier T, Thalmeir S, Kempe D, Sänger H-L, Wassenegger M. 1999. Heavy de novo methylation at symmetrical and nonsymmetrical sites is a hallmark of RNA-directed DNA methylation. Nucleic Acids Res 27:1625-1634.

Pélissier T, Wassenegger M. 2000. A DNA target of $30 \mathrm{bp}$ is sufficient for RNA-directed DNA methylation. RNA 6:55-65.

Rountree MR, Selker EU. 1997. DNA methylation inhibits elongation but not initiation of transcription in Neurospora crassa. Genes \& Dev 11:2383-2395.

Sambrook J, Fritsch EF, Maniatis T. 1989. Molecular cloning: A laboratory manual, 2nd ed. Cold Spring Harbor, New York: Cold Spring Harbor Laboratory Press.

Shepardson S, Esau K, McCrum R. 1980. Ultrastructure of potato leaf phloem infected with potato leafroll virus. Virology 105:379392.

Stam M, Mol JNM, Kooter JM. 1997. The silence of genes in transgenic plants. Ann Bot 79:3-12.

Sutherland E, Coe L, Raleigh EA. 1992. McrBC: A multisubunit GTPdependent restriction endonuclease. J Mol Biol 225:327-348.

Symons RH. 1997. Plant pathogenic RNAs and RNA catalysis. Nucleic Acids Res 25:2683-2689.

Tabara H, Sarkissian M, Kelley WG, Fleenor J, Grishok A, Timmons L, Fire A, Mello CC. 1999. The rde-1 gene, RNA interference, and transposon silencing in C. elegans. Cell 99:123-132.

Taliansky M, Barker H. 1999. Movement of luteoviruses in infected plants. In: Smith HG, Barker H, eds. Luteoviruses. Warwick: CMI/ AAB. pp 69-84.

Voinnet O, Vain P, Angell S, Baulcombe DC. 1998. Systemic spread of sequence-specific transgene RNA degradation in plants in initiated by localized introduction of ectopic promoterless DNA. Cell 95:177-187.

Wang M-B, Cheng Z, Keese P, Graham MW, Larkin PJ, Waterhouse PM. 1998. Comparison of the coat protein, movement protein and RNA polymerase gene sequences of Australian, Chinese, and American isolates of barley yellow dwarf virus transmitted by Rhopalosiphum padi. Arch Virol 143:1005-1013.

Wang M-B, Waterhouse PM. 2000. High efficiency silencing of a $\beta$-glucuronidase gene in rice is correlated with repetitive transgene structure but is independent of DNA methylation. Plant Mol Biol 43:67-82.

Wassenegger M, Heimes S, Riedel L, Sänger HL. 1994. RNAdirected de novo methylation of genomic sequences in plants. Cell 76:567-576.

Wassenegger M, Pélissier T. 1999. Signaling in gene silencing. Trends Plant Sci 4:207-209.

Waterhouse PM, Smith NA, Wang MB. 1999. Virus resistance and gene silencing: Killing the messenger. Trends Plant Sci 4:452-457.

Zamore PD, Tuschl T, Sharp PA, Bartel DP. 2000. RNAi: Doublestranded RNA directs the ATP-dependent cleavage of mRNA at 21 to 23 nucleotide intervals. Cell 101:25-33. 

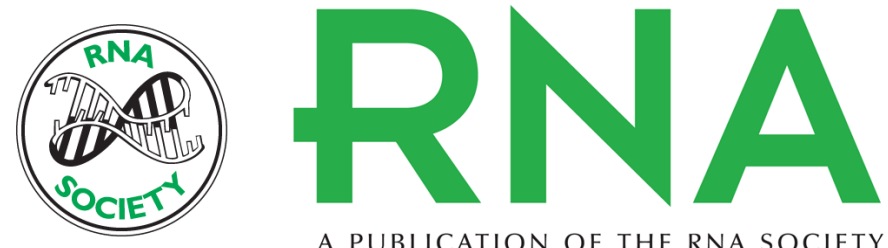

A PUBLICATION OF THE RNA SOCIETY

\section{Replicating satellite RNA induces sequence-specific DNA methylation and truncated transcripts in plants.}

M B Wang, S V Wesley, E J Finnegan, et al.

RNA 2001 7: 16-28

\section{License}

Email Alerting Receive free email alerts when new articles cite this article - sign up in the box at the Service top right corner of the article or click here. 